\title{
TECHNOLOGICAL AND ECONOMIC DESIGN OF ASPHALT MIXTURE COMPOSITION BASED ON OPTIMIZATION METHODS
}

\author{
Henrikas SIVILEVIČIUS ${ }^{a}$, Kęstutis VISLAVIČIUSS ${ }^{\mathrm{b}}$, Justas BRAŽIŪNAS ${ }^{\mathrm{a}}$ \\ ${ }^{a}$ Department of Transport Technological Equipment, Vilnius Gediminas Technical University, \\ Plytines g. 27, LT-10105 Vilnius, Lithuania \\ ${ }^{b}$ Department of Strength of Materials and Engineering Mechanics, Vilnius Gediminas \\ Technical University, Sauletekio al. 11, LT-10223 Vilnius, Lithuania
}

Received 07 March 2017; accepted 24 March 2017

\begin{abstract}
The asphalt pavement made of high quality materials and having the optimal composition best resists destructive effects of environmental factors and vehicles. The optimal content of the mineral materials of the asphalt mixture and a bituminous binder is selected employing calculation and experimental methods. The properties of the designed asphalt mixture must meet the requirements of technical specifications thus reducing its cost. The paper presents algorithms for simulating the composition of the asphalt mixture applying mathematical programming techniques. The algorithms allow designing the asphalt mixture with minimal bitumen content, a low cost of the mineral part and the densest gradation assessing technological requirements for producing the mixture. Optimal bitumen content is calculated considering bitumen capacities specified for different types of rock and determined employing the most recent standard sieves screening for narrow fractions. For verifying the new proposed algorithms, a numerical experiment on the materials most commonly used in asphalt mixing plants was done. The analysis of findings indicates that the application of the algorithms assist in comparing real results.
\end{abstract}

Keywords: asphalt mixture, design of composition, optimization, gradation, bitumen content, cost minimization, bitumen capacity, numerical experiment.

JEL Classification: C02, C61, C74, L79.

\section{Introduction}

The asphalt mixture consists of asphalt (bitumen), coarse and fine aggregate and a number of additives occasionally used for improving its engineering properties. The purpose of designing the mixture is selecting optimal asphalt content for a desired structure of aggregate to meet the prescribed criteria (Roberts et al. 2002). The overall performance of the asphalt concrete (AC) mixture depends on its composition, including the properties, proportions

Corresponding author Kęstutis Vislavičius

E-mail: kestutis.vislavicius@vgtu.lt 
and distributions of ingredients. For the existing methods of designing the asphalt mixture, however, there is a missing link between the composition of the mixture and overall properties and performance (Liu et al. 2011; Zulkati et al. 2012). The composition of the asphalt mixture is designed applying the Hveem and Marshall methods (Asphalt Institute 1993; $\mathrm{Du}$, Kuo 2011) and the Superpave method (Transportation Research Board 2011; Ahmad et al. 2012). The Superpave design mainly uses volumetric properties for the mix design, similar to the Marschall method. The design air void is approximately $4 \%$. The main differences between these two methods are as follows. Asphalt specimens for Superpave were prepared using the gyratory compact with kneading actions which can reliably replicate the roller compaction in the field instead of the Marshall compactor which can provide only the static compaction. The gyratory compaction level varied with design traffic and the average maximum temperature in a design location (Jitsangiam et al. 2013).

The effect on Marshall Stability (MS) of hot-mix asphalt (HMA) parameters which are the particle diameters of aggregates, quantity of bitumen in the HMA, different environmental temperatures and the exposure times was closely investigated (Özgan et al. 2013). The objective in the design of asphalt mixtures is to optimize the properties of the mixture with respect to the stability, durability, flexibility, fatigue resistance, skid resistance, permeability, and workability. This is often accomplished with the evaluation of the volumetric properties of the mixture (Vavrik et al. 2002).

Bitumen is a viscoelastic multiphase material that includes colloidal microstructures consisting of elastic solid aggregates and a viscoelastic matrix. Based on solubility parameters, bitumen components fall into four categories embracing saturates, aromatics, resins and asphaltenes (Behzadfar, Hatzikiriakos 2013). The quality of road bitumen in asphalt mixtures is one of the most important factors affecting the performance of the entire pavement structure during its service. In particular, the type and refining technology of crude oil are the most important aspects having impact on bitumen properties (Paliukaite, Vaitkus 2015). Asphalt mastics are generally made by mixing asphalt binder (i.e. bitumen) with certain percentages of mineral fillers. As such, it can be treated as suspension, in which bitumen is the fluid phase and the fillers are the particles (Hasemi et al. 2012).

The shape, size, angularity and surface texture properties of coarse aggregates were studied by Zhang et al. (2012). The void contents of different sized limestone and basalt aggregates in loose condition were tested to validate the angularity and surface (AT) index. The results indicate that the AT index is effective for characterizing the combined effect of the coarse aggregate angularity and surface texture.

The effect of compaction degree and binder content on the performance properties of asphalt mixtures of asphalt concrete type for wearing and binder courses are described in the paper by Hýzl et al. (2016). The measurements of the selected asphalt mixtures were performed taking into account stiffness modulus and conducting a two-point bending test on trapezoidal shaped specimens, fatigue characteristics and resistance against frost cracking considering a thermal stress restrained specimen test.

Mineral materials interact with the bituminous binder (Yiqiu et al. 2012) a certain part of which is absorbed by aggregates (Luo, Lytton 2013; Doyle et al. 2012). Also, bitumen makes diffusive interaction with water, which reduces the coating strength of asphalt 
(Vasconcelos et al. 2011). Adhesion between asphalt-aggregate and cohesion within asphalt mastic has a significant effect on the performance of asphalt mixtures. Conventional testing methods and studies typically focus only on one of the damaged models (adhesion or cohesion), although considering real asphalt mixtures (asphalt-aggregate system), these two modes of failure may happen together depending on the material and loading conditions (Yi et al. 2016). Experimental results showed that the significant effects of temperature and loading rate on interface binding characteristics.

The temperature of the asphalt mixture has the biggest influence on the compaction of asphalt mixtures and their properties. The temperature of the asphalt mixture affects the viscosity of bitumen and achievement in the highest density of the asphalt mixture (Androjić, Dimter 2015). The temperature of the asphalt mixture is not homogenous during its laying process. The carried out theoretical calculations confirmed by laboratory tests and measurements on the road allow predicting a drop in the speed of temperature in these areas (Mieczkowski 2015).

The mechanical properties of hot-mix asphalt (HMA) mixtures are often characterized by its viscoelastic properties. Viscoelasticity coupled with the thermo-mechanical nature of asphalt offers time-temperature dependence on the mechanical properties of HMA mixtures (Alam, Hammoum 2015).

Underwood and Kim (2013) developed a microstructural hypothesis for asphalt concrete $(\mathrm{AC})$ in order to provide a basis for multi-scale experimental investigation. The hypothesis is consistent with the belief that $\mathrm{AC}$ can be considered as a four-scale assemblage of components having different length, scale, binder, mastic fine aggregate matrix (FAM) and AC.

Rutting is considered the most frequent and negative type of pavement distress. It significantly depends on the type of the pavement structure, the kind and quality of materials used for different types of structure layers, pavement construction techniques and quality (Vaitkus, Paliukaite 2013). Rutting is a function of dynamic modulus and gradation (Apeagyei 2011). Ruts form in the used asphalt pavement, and therefore their geometric parameters may vary (Sivilevičius, Vansauskas 2013).

The resistance of asphalt mixtures against permanent deformation is one of the most important requirements that have to be verified in the process of designing asphalt mixtures (Remišová 2015). The presented study investigates the characteristics of resistance to rutting asphalt concrete mixtures (eight mixtures of AC 11 form different procedures determined by a triaxial cycling compression test). Thus, it is possible to claim that an expensive procedure for the rutting test can assist with a simple test carried out in the dynamic shear rheometer following a procedure for the initial mixture design (Gajewski et al. 2015).

Typically, aggregate gradation is selected to meet the specifications of Superpave mix design. The porosity of the dominant aggregate size range (DASR), which is the primary structural network of aggregates, has been extensively validated as a tool for evaluating the coarse aggregate structure of laboratory and field asphalt mixtures (Guarin et al. 2013). The structure of aggregate depends on gradation and is an important factor in determining the volumetric properties of hot-mix asphalt (HMA). This approach is time consuming and often results in suboptimal HMA mixtures (Awuah-Offei, Askari-Nasab 2011). This study 
presents linear programming optimization models and attendant solution procedures that minimize HMA aggregate costs and produce high-quality HMA.

The procedure for designing the asphalt mixture specifies a range in the content of air voids from $3 \%$ to $5 \%$. However, the actual variability in air void content in the field tends to be greater than that because of compaction variability and temperature segregation (Chang et al. 2002). Air voids play an important role in influencing the performance of asphalt mixtures (Mohammad et al. 2004; Dubois et al. 2010; Crouch et al. 2002). Seo et al. (2007) presents an experimental study on developing air void models for dynamic modulus and predicting the performance of the asphalt concrete mixture. The study by Kassem et al. (2011) utilized several mechanical tests to characterize the influence of air void distributions on the mechanical properties and response of asphalt mixtures. Overlay test results showed that specimens with more uniform air void distribution had less variability in terms of resistance to fatigue cracking compared with specimens with less uniform air void distribution. Castillo and Caro (2014) evaluated the role of air void (AV) variability in asphalt mixtures in the thermo-mechanical response of asphalt courses. The presented methodology combines finite element (FE) modelling with a stochastic technique called random fields. The technique is used for generating probable spatial AV distributions in the geometry of compacted asphalt courses.

Assessing the air void content of hot-mix asphalts (HMAs) is a vital and crucial factor in the procedures for quality control and quality assurance (QC/QA). Layer geometry, mix composition, specific gravities of aggregate and the asphalt binder as well as compaction characteristics (i.e. energy) together determine air void content (Praticó, Moro 2012).

The previous studies indicated that criteria for the present mixture design, including voids in mineral aggregates, gradation control points and effective asphalt content, did not capture all critical aspects of gradation and the volumetric properties of the mixture were found to be strongly related to rutting and cracking performance (Chun et al. 2012). The study (Xie, Watson 2004) compared difference in air voids, optimal asphalt content and voids in the mineral aggregate (VMA) employing saturated surface dry (SSD) and CoreLok methods for determining bulk specific gravity of the compacted specimen.

Sánchez-Leal et al. (2011) demonstrates the application of the polygon of voids, or "polyvoids", as an analytical technique for producing a hot-mix asphalt (HMA) job-formula based only on the specifications of voids, for creating Superpave hot-mix asphalt design and for conducting analysis. Polyvoids appear as one of original analytical tools for RAMCODES (acronym for a rational methodology of compacted geo-material densification and strength analysis). The centroid of polyvoids is proposed as a job-formula or optimalbinder content for HMA design based on the specifications of voids only.

A design parameter of voids in the mineral aggregate (VMA) is crucial to the current procedure for Superpave mix design that links the properties of the hot-mix asphalt (HMA) mixture to field performance (Kandhal, Chakraborty 1996). Shen and Yu (2011) analysed the simulation of aggregate packing and discrete-element modelling (DEM) to link the property of aggregate gradation to the VMA of HMA. Thus, a new definition characterizing traditional dense-graded aggregate gradation of three types, including coarse-graded, medium-graded and fine-graded, was proposed. 
Heterogenous air void distribution is a common phenomenon in asphalt mixtures and is closely related to the behaviour of the asphalt mixture. Air void distribution within the specimen of the asphalt mixture is related to several factors such as compaction effort, the method of compaction (equipment) and aggregate gradation (Chen et al. 2013). The performed research demonstrated that the simulation of the discrete element method (DEM) could be a potentially helpful tool for analysing asphalt mixture compaction and selecting appropriate aggregates for asphalt mixture design. A semi-analytical model for evaluating a binary normal contact of spherical particles interacting via weaker multi-layered interface was suggested and its applicability for modelling asphalt mixtures was investigated (Rimša et al. 2014; Collop et al. 2006).

It is believed that stone-on-stone contact is important for open-graded friction course (OGFC) mixes to minimize the potential for rutting (Watson et al. 2004). Therefore, the same requirements for voids in coarse aggregate (VCA) were adopted to OGFC mixes as they had been developed for stone matrix asphalt mixtures. The objective of this study is to verify the VCA concept of determining stone-on-stone contact within OGFC mixtures using digital imaging techniques such as the analysis of particle contacts and the distribution of air voids size.

The thickness of the bitumen liner covering the mineral grains of asphalt affects the strength of the layer of the mixture and the pavement produced from it (Radovskiy 2003; Sengoz, Topal 2007; Oliver 2011; Hmoud 2011).

The study (Sengoz, Agar 2007) is aimed at determining the relationship between the different thickness of the asphalt liner and susceptibility characteristics of the water of hot mix asphalt (HMA) in order the optimal thickness of the asphalt liner that minimizes moisture damage to HMA can be obtained. The optimum range of the thickness of the asphalt liner obtained from the figures plotted between the thickness of the asphalt liner and modified Lottman test results is in the range from 9.5 to $10.5 \mu \mathrm{m}$. Research (Chen et al. 2015) is focused on how volumetric properties and performance tests on asphalt concrete are influenced by the $100 \%$ replacement of coarse natural aggregates with basic oxygen furnace (BOF) slag. According to the results of mixture design, except for BOF slag asphalt mixture with an upper gradation curve, liner thickness varies from 6 to $9 \mu \mathrm{m}$. The thickness of the bitumen liner can be determined using the methods given in Appendix 4 (Read, Whiteoak 2003). The typical thickness of the bitumen liner is as follows: the thickness of dense coated macadam makes $>5 \mu \mathrm{m}$, that of hot rolled asphalt reaches $>7 \mu \mathrm{m}$ and that of porous asphalt counts $>12 \mu \mathrm{m}$.

Petroleum bitumen used for producing road surfaces slowly reacts with atmospheric oxygen. The reaction eventually leads to the embrittlement of bitumen and failure on the surface under traffic stresses and, for this reason, is of great practical importance. The extent of the reaction is not uniform throughout the surfacing layer but is dependent on the diffusion of oxygen from the surface exposed to the atmosphere (Herrington 2012; Jin et al. 2013).

The properties (aggregate gradation and volumetric quantities) of the mixture, the rate of loading and environmental conditions are the most important factors that affect the dynamic modulus (|E*|) (Zaciada et al. 2014). The main objective of this study is to develop a 
rational approach to investigating and simulating the effect of air voids and asphalt content on $\left|E^{*}\right|$ master curves and consequently predict pavement performance.

The optimally designed asphalt mixture must be produced in an asphalt mixing plant (AMP) so that the content of its components differed insignificantly from the job-mix formula (JMF). Bitumen content in the produced asphalt mixture depends on the technological parameters of the batcher (Bražiūnas, Sivilevičius 2010). The quality of the produced asphalt mixture depends on the manufacturing temperature and duration of mixing of materials, which impact short-term aging processes of bitumen (Bražiūnas et al. 2013). The sequence of dosing and mixing materials affects the quality of the produced asphalt mixture. In order to improve the mechanical properties of hot mix asphalt, the mixing method was considered in research by Kok and Kuloglu (2011). The new method was mainly based on pre-coating coarse aggregate with an appropriate amount of optimal binder content. Then, the coated coarse aggregate was mixed with fine aggregate and filler and the remaining optimum asphalt content. A mixing plant for the two-phase mixing method was designed for manufacturing hot mix asphalt.

Due to segregation processes, the mineral materials used for producing the asphalt mixture are non-homogeneous. Vislavičius and Sivilevičius (2013) present the algorithm for predicting the composition of the mineral materials consistent in the recycled hot-mix asphalt taking into consideration variations in the gradation of all mineral materials and the reclaimed asphalt pavement in the absence of random batching errors. The technological process of producing the asphalt mixture must be continuously monitored applying effective methods (Awuah-Offei, Askari-Nasab 2009).

The general principles of simulating the physical and mechanical properties of conglomerates were presented in research publication by (Vislavičius 2000). The principles were applied for asphalt mixtures (Vislavičius 2002) when gradation was determined using the sets of old laboratory sieves.

\section{Problem formulation}

\subsection{Mathematical analogue for determining optimal bitumen content}

The problem of determining optimal bitumen content is formulated as follows: using the available original mineral materials, the curves of gradation and bitumen capacities of certain narrow fractions of which are known, the composition of the asphalt mixture satisfying quantity limits on the percent passing of all mineral materials through sieves and ensuring high physical-mechanical properties of asphalt pavement under minimal bitumen content must be designed. Bitumen content in the asphalt mixture can be optimal when a) it ensures the required physical-mechanical properties of the asphalt mixture; $b$ ) its content in the asphalt mixture is the lowest as bitumen is the most expensive component of the asphalt mixture. To avoid ambiguity, the content of bitumen ensuring the best physical-mechanical properties of asphalt pavement will be called "the required". It is clear that calculation accuracy depends only on how precisely the bitumen capacity of certain narrow fraction is 
determined. Thus, optimal bitumen content is treated as that of the minimum required bitumen and is determined by changing the gradation of the designed asphalt mixture.

Suppose, we have mineral materials $m$ to design some asphalt mixture using a minimal content of the required bitumen. The gradation of all mineral materials is known, i.e. we know coefficients $\alpha_{j k}$ indicating the content of the $k$-th narrow fraction (\%) in the $j$-th mineral material $(j=1,2, \ldots, m, k=1,2, \ldots, r$; where $r$ is the number of the narrow fractions of a mineral material). Also, bitumen capacities $\beta_{j k}$ of all fractions of mineral materials indicating the content $(\%)$ of the required bitumen of the $k$-th narrow fraction of the $j$-th mineral material are known. The problem will be resolved if the content of all narrow fractions of every mineral material present in the asphalt mixture is identified, i.e. variables $x_{j k}$ indicating the content of the $k$-th narrow fraction of the $j$-th mineral material (in parts of the unit) in the asphalt mixture will be found.

Thus, variables and all known values are defined, and only the object function and necessary conditions that must be satisfied by the designed asphalt mixture have to be recorded.

Let's express coefficients $\alpha_{j k}$, in the parts of the unit. Then, product $\alpha_{j k} \cdot x_{j k}$ will also denote the content of the $k$-th narrow fraction of the $j$-th mineral material in the parts of the unit. Therefore, when the content of the narrow fraction of the mineral material is multiplied by the corresponding bitumen capacity, the required bitumen amount of the $k$-th narrow fraction of the $j$-th mineral material is obtained (\%): $\beta_{j \mathrm{k}} \cdot \alpha_{j k} \cdot x_{j k}$. Expression $\sum_{k=1}^{r} \beta_{j k} \cdot \alpha_{j k} \cdot x_{j k}$ denotes the required bitumen content of all narrow fractions of mineral material $j$, and, similarly to expression $\sum_{j=1}^{m} \sum_{k=1}^{r} \beta_{j k} \cdot \alpha_{j k} \cdot x_{j k}$, conveys the required bitumen content of all mineral materials. The obtained bitumen content has to make minimum. Hence, the object function of the problem is as follows:

$$
\sum_{j=1}^{m} \sum_{k=1}^{r} \beta_{j k} \cdot \alpha_{j k} \cdot x_{j k} \rightarrow \min .
$$

Variables $x_{j k}$ must minimize the object function (1) and satisfy certain conditions. First, they must comply with the requirements set out for the gradation of the mineral part of the asphalt mixture, i.e. satisfy quantity limits on the percent passing of all mineral materials through sieves. Thus, denote these limited quantities by symbols $p_{L, i}$ and $p_{U, i}$ where $i=1,2$, $\ldots, n, n$ is the number of sieves. Next, the contents of the mineral part of the designed mixture that pass through a certain sieve have to be analytically expressed. The sum of products $\sum_{k=1}^{r} \alpha_{j k, i} \cdot x_{j k}$ indicates the content of the $j$-th mineral material in the mixture that passes through the $i$-th sieve. Therefore, limits to the gradation of the designed asphalt mixture on the sieve having the smallest meshes through which the smallest particles of all mineral materials pass will have expression $p_{L, 1} \leq \sum_{j=1}^{m} \sum_{k=1}^{r} \alpha_{j k, 1} \cdot x_{j k} \leq p_{U, 1}$. The second sieve will be necessary for considering the fact that the contents of the two smallest fractions of all mineral materials pass through it, the third sieve takes three smallest fractions, etc. Hence, $n$ expressions must be included in the mathematical analogue of the problem designed:

$$
p_{L, i} \leq \sum_{j=1}^{m} \sum_{k=1}^{r} \alpha_{j k, i} \cdot x_{j k} \leq p_{U, i}, i=1,2, \ldots, n .
$$


Another limitation to variables $x_{j k}$ is related to the fact that, in most cases, a designer operates mineral materials with certain gradation rather than with certain separate narrow fractions of mineral materials. Therefore, the contents of all narrow fractions of certain mineral materials must be the same, i.e. the contents of narrow fractions must satisfy the following condition:

$$
x_{j 1}=x_{j 2}=\ldots=x_{j k}=\ldots=x_{j r}, j=1,2, \ldots, m .
$$

This means that the number of variables is not $j \cdot r$ but $j$. They are expressed by the parts of the unit, and therefore have to meet the following condition:

$$
\sum_{j=1}^{m} x_{j 1}=1 \text {. }
$$

In this case, to simplify the expression, the first fraction is noted. Formula (3) clearly indicates that, here, the content of any narrow fraction of mineral materials could be entered.

The last condition that ensures the reality of the problem is as follows:

$$
x_{j 1} \geq 0, j=1,2, \ldots, m .
$$

All above discussed equations and inequalities are necessary. To complete the perfect mathematical analogue of the problem, we have to include an additional inequality:

$$
\sum_{j=1}^{m} d_{j v} \cdot x_{j 1} \leq h_{v}, v=1,2, \ldots, s,
$$

where $d_{j v}$ is the coefficient of the $v$-th additional inequality of the $j$-th mineral material; $h_{v}$, is the free member of the $v$-th additional inequality $v ; s$ is the number of additional inequalities (6) that mathematically express technological, economic, etc. limitations (there may be none of them). For example, these inequalities can be used for limiting a maximum or minimum quantity of a certain mineral material in a mixture.

Thus, the mathematical analogue for determining the minimum content of the required bitumen is as follows:

$$
\begin{aligned}
& \sum_{j=1}^{m} \sum_{k=1}^{r} \beta_{j k} \cdot \alpha_{j k} \cdot x_{j k} \rightarrow \text { min, } \\
& p_{L, 1} \leq \sum_{j=1}^{m} \sum_{k=1}^{r} \alpha_{j k, 1} \cdot x_{j k} \leq p_{U, 1}, i=1,2, \ldots, n, \text { (b) } \\
& x_{j 1}=x_{j 2}=\ldots=x_{j k}=\ldots=x_{j r}, j=1,2, \ldots, m, \text { (c) } \\
& \sum_{j=1}^{m} d_{j v} \cdot x_{j 1} \leq h_{v}, v=1,2, \ldots, s, \\
& \sum_{j=1}^{m} x_{j 1}=1, \\
& x_{j 1} \geq 0, j=1,2, \ldots, m .
\end{aligned}
$$




\subsection{Algorithm for calculating the minimal cost of mineral materials present in the asphalt mixture}

The presented mathematical analogue is universal and suitable for simulating various asphalt mixtures. Suppose that an asphalt mixture of the minimal cost of mineral materials needs to be designed. If $f_{j}$ is the cost of the unit of the $j$-th mineral material, following equation (3), the object function of the mathematical analogue is

$$
\sum_{j=1}^{m} f_{j} \cdot x_{j 1} \rightarrow \min .
$$

The full cost of the asphalt mixture is obtained by the sum of the costs of its mineral part and bitumen. If $f_{b}$ is the cost of the bitumen unit, the cost of the asphalt mixture is

$$
c=\sum_{j=1}^{m} f_{i} \cdot x_{i 1}+f_{b} \sum_{j=1}^{m} \sum_{k=1}^{r} \beta_{j k} \cdot \alpha_{j k} \cdot x_{j k} .
$$

\subsection{Algorithm for simulating the densest asphalt mixture}

Suppose that an asphalt mixture having the densest gradation of mineral materials has to be designed. The densest asphalt mixture is obtained when a gradation curve of the mineral part of the designed asphalt mixture corresponds to a gradation curve of the ideal asphalt mixture. The gradation curve of the ideal asphalt mixture is received reserving the average limit values of the contents of mineral particles that pass through certain sieves $\left(p_{L}+p_{U}\right) / 2$. It is evident that real mineral materials cannot be enough for achieving ideal density. To obtain the densest asphalt mixture, the paper proposes to proportionally narrow the interval between the specified points of lower and upper specification limits, i.e. to proportionally and tightly put one limit curve $p_{L}$ to another $p_{U}$. The calculation is completed when the following narrowing does not result in the solution. Obviously, the smaller is the step of narrowing the interval, the denser gradation of the asphalt mixture is obtained.

Another useful example of the practical application of the mathematical analogue (7) is related to assessing the availability of mineral materials for producing the asphalt mixture. Using it is possible to determine whether the available mineral materials will succeed in producing the asphalt mixture of the gradation of the desired type.

\section{Numerical experiment}

\subsection{The gradation of mineral materials and the asphalt mixture}

The asphalt mixing plant (AMP) stockpiles and silos are used for storing cold mineral materials before the season of producing the mixture. To perform a numerical experiment, six minerals, including non-activated dolomite imported filler (IF), natural quartz sand (NS), granite sifting (GS), crushed granite 4/8 (CG 4/8), crushed granite 8/11 (CG 8/11) and crushed granite 11/16 (CG 11/16) were selected. The produced asphalt mixture will contain road bitumen at grade $70 / 100$ the content of which in the asphalt mixture should 
make not less than $B_{\min }=5.2 \%$. The asphalt mixture of asphalt concrete type AC $16 \mathrm{VS}$ of the surface layer of the pavement should be designed. Data describing the gradation of the designed asphalt mixture and mineral materials are presented in Table 1.

The gradation curves of mineral materials, the curves of lower and upper specification limits $p_{L}$ and $p_{U}$ of the asphalt mixture AC $16 \mathrm{VS}$ of the pavement and the curve $\left(p_{L}+p_{U}\right) / 2$ of the asphalt mixture composition of the most even part of the mineral material are shown in Figure 1.

Table 1. The gradation of stockpile materials and gradation limits in the AC 16 VS asphalt mixture (percent passing)

\begin{tabular}{ccccccccc}
\hline \multirow{2}{*}{$\begin{array}{c}\text { Sieve size } \\
(\mathrm{mm})\end{array}$} & \multicolumn{3}{c}{ Gradation of the stockpile mineral materials } & & \multicolumn{2}{c}{$\begin{array}{c}\text { Limits on asphalt } \\
\text { mixture gradation }\end{array}$} \\
\cline { 2 - 9 } & IF & NS & GS & CG4/8 & CG8/11 & CG11/16 & $p_{L, i}$ & $P_{U, i}$ \\
\hline 0.063 & 83.8 & 4.2 & 11.3 & 2.6 & 2.1 & 1.8 & 5 & 9 \\
\hline 0.125 & 93.4 & 10.1 & 16.7 & 2.9 & 2.3 & 2.0 & 7 & 17 \\
\hline 0.25 & 97.9 & 21.8 & 27.5 & 3.4 & 2.5 & 2.3 & 14 & 24 \\
\hline 0.5 & 99.5 & 39.6 & 35.2 & 4.0 & 2.9 & 2.7 & 20 & 30 \\
\hline 1 & 99.8 & 52.9 & 45.7 & 4.7 & 3.4 & 3.1 & 26 & 36 \\
\hline 2 & 100 & 64.2 & 53.2 & 8.8 & 4.1 & 3.8 & 35 & 45 \\
\hline 5.6 & 100 & 87.4 & 91.8 & 16.7 & 6.9 & 5.4 & 54 & 66 \\
\hline 8 & 100 & 96.1 & 100 & 90.1 & 12.2 & 9.2 & 62 & 76 \\
\hline 11.2 & 100 & 100 & 100 & 99.3 & 94.3 & 14.7 & 70 & 85 \\
\hline 16 & 100 & 100 & 100 & 100 & 99.1 & 89.0 & 90 & 100 \\
\hline 22.4 & 100 & 100 & 100 & 100 & 100 & 99.1 & 100 & 100 \\
\hline Asphalt binder - road bitumen at grade 70/100 & In AC 16 VS mixture $B_{\text {min }} \geq 5.2 \%$ \\
\hline
\end{tabular}

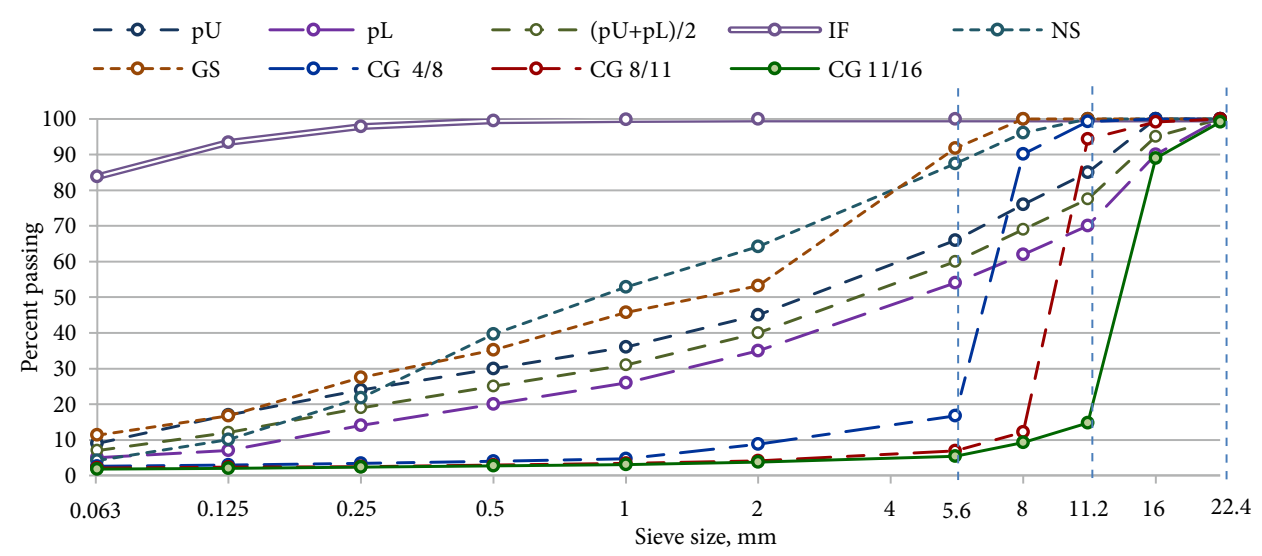

Fig. 1. The gradation curves of mineral materials, limit curves and the gradation curve of the ideal asphalt mixture composition 


\subsection{Determining bitumen capacity}

Using the old set of sieves, bitumen capacities $\beta_{j k}$ of the narrow fractions of granite, quartz sand and dense limestone are displayed in Table 2 . The capacities were established by Korolev (1986) who employed oil bitumen BND 90/130 that was equalled to road bitumen of penetration 70/100 used for producing hot-mix asphalt mixtures in Lithuania. The dynamics of changing the size of standard laboratory sieve mesh in the Republic of Lithuania is presented in Table 3.

Table 2. Grain sizes of narrow fractions and capacities of the bitumen of different rocks obtained applying standard laboratory sieves of the old-type set and using oil bitumen BND 90/130

\begin{tabular}{cccccc}
\hline \multirow{2}{*}{ No } & \multirow{2}{*}{$\begin{array}{c}\text { Narrow } \\
\text { fraction }\end{array}$} & Granite & Quartz sand & Dense limestone & $\begin{array}{c}\text { Average size } \bar{d} \text { of the } \\
\text { narrow fraction particle }\end{array}$ \\
\cline { 3 - 6 } 1 & $0-0.071$ & 18.0 & 14.0 & 16.0 & 0.0333 \\
\hline 2 & $0.071-0.14$ & 8.4 & 7.0 & 9.4 & 0.1016 \\
\hline 3 & $0.14-0.315$ & 7.4 & 6.1 & 7.3 & 0.2158 \\
\hline 4 & $0.315-0.63$ & 6.4 & 4.8 & 7.0 & 0.4545 \\
\hline 5 & $0.63-1.25$ & 5.9 & 4.6 & 6.0 & 0.9049 \\
\hline 6 & $1.25-3$ & 5.7 & 3.8 & 5.3 & 1.9990 \\
\hline 7 & $3-5$ & 5.6 & 3.3 & 4.6 & 3.9153 \\
\hline 8 & $5-10$ & 5.2 & - & 3.2 & 12.2136 \\
\hline 9 & $10-15$ & 4.7 & - & 3.0 & 19.5764 \\
\hline 10 & $15-25$ & 4.5 & - & 2.9 & \\
\hline
\end{tabular}

Table 3. The dynamics of changing the size of standard laboratory sieve mesh in the Republic of Lithuania

\begin{tabular}{llllllllllllll}
\hline $\begin{array}{c}\text { Service time and a } \\
\text { normative document }\end{array}$ & \multicolumn{8}{c}{ Length of the side of the square mesh of the sieve or the diameter } \\
of the round* mesh, mm
\end{tabular}


The first step is to estimate the average size $\bar{d}_{k}$ of the particles passing through the sieve mesh of size $d_{i+1}$ and retaining the sieve mesh of size $d_{i}$. The equation used for the $k$-th narrow fraction was taken from Evaluation (Highway Research Board 1967):

$$
\bar{d}_{k}=\frac{0.4343\left(d_{i+1}-d_{i}\right)}{\log \left(\frac{d_{i+1}}{d_{i}}\right)} k=1,2, \ldots, r, i=1,2, \ldots, n .
$$

When standard sieves $d_{i+1} / d_{i}=2$ are used, equation (10) is simplified to

$$
\bar{d}_{k}=1.443\left(d_{i+1}-d_{i}\right) \text {. }
$$

The application of formula (10) assisted in calculating the geometrical means $\bar{d}_{k}$ of the narrow fractions of the old set of sieves presented in the last column of Table 2.

The use of regression analysis helped with establishing the correlation between the geometrical means $\bar{d}_{k}$ and bitumen capacity $\beta_{j k}$ of narrow fractions. For investigating the correlation, the following formula was used:

$$
\beta_{j k}=A_{j k} \cdot \bar{d}_{k}^{B j k}
$$

where $A_{j k}$ and $B_{j k}$ are the free members of the regression equation for the $k$-th narrow fraction of the $j$-th mineral material.

The values of determination coefficients $R^{2}$ close to the unit show a strong correlation between experimental data on bitumen capacity $\beta_{j k}$ and geometrical means $\bar{d}_{k}$ of the narrow fractions obtained employing the sieves from the old set. The values make $R^{2}=0.800$ for granite, $R^{2}=0.965$ - for quartz sand and $R^{2}=0.916$ for dense limestone. The use of other regression equations having different forms had little effect on $R^{2}$ values. Therefore, regression equations presented in Figure 2 were used for determining bitumen capacities $\beta_{j k}$ of the narrow fractions of the mineral materials obtained sieving particles through the sieves of the new set. For that purpose, equation (10) assisted in calculating the geometrical means $\bar{d}_{k}$ of the sieves of the new set ( $2^{\text {nd }}$ column in Table 4$)$. Regression equations in

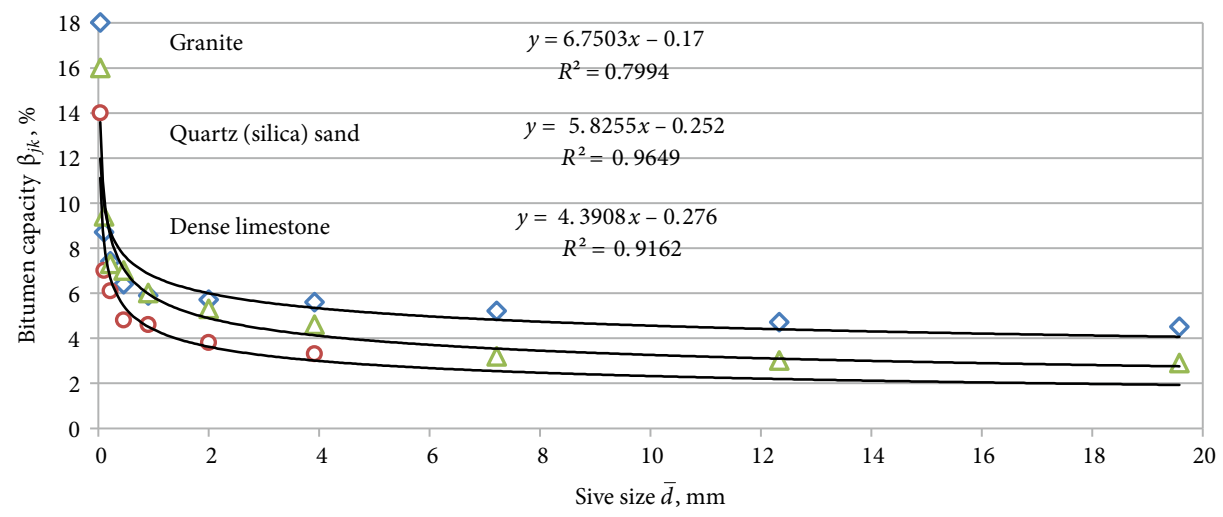

Fig. 2. The dependence of bitumen capacity $\beta_{j k}$ of the narrow fractions of mineral materials from different rocks on their average diameter $\bar{d}$ obtained using a set of old standard laboratory sieves 
Figure 2 indicate that using the geometrical means $\hat{d}_{k}$ of the sieves of the new set instead of the geometrical means $\bar{d}_{k}$ of the sieves of the old set helped with calculating bitumen capacities $\beta_{j k}$ of the narrow fractions of the new set of sieves (see Table 4).

Table 4. Bitumen capacities (\%) of the narrow fractions of mineral materials calculated from regression equations presented in Figure 2

\begin{tabular}{cccccccc}
\hline $\begin{array}{c}\text { Size of the } \\
\text { narrow fraction, } \\
(\mathrm{mm})\end{array}$ & $\begin{array}{c}\text { Average size } \\
\hat{d}, \mathrm{~mm}\end{array}$ & \multicolumn{6}{c}{ Bitumen capacity of the narrow fraction of the mineral material } \\
\cline { 3 - 8 } & & IF & NS & GS & CG4/8 & CG8/11 & CG11/16 \\
\hline Less than 0.063 & 0.02971 & 15.37 & 11.59 & 12.27 & 12.27 & 12.27 & 12.27 \\
\hline $0.063-0.125$ & 0.09049 & 11.31 & 8.52 & 10.16 & 10.16 & 10.16 & 10.16 \\
\hline $0.125-0.25$ & 0.18034 & 9.35 & 7.04 & 9.03 & 9.03 & 9.03 & 9.03 \\
\hline $0.25-0.5$ & 0.3607 & 7.72 & 5.82 & 8.03 & 8.03 & 8.03 & 8.03 \\
\hline $0.5-1$ & 0.7214 & 6.38 & 4.81 & 7.14 & 7.14 & 7.14 & 7.14 \\
\hline $1-2$ & 1.4427 & 5.27 & 3.97 & 6.34 & 6.34 & 6.34 & 6.34 \\
\hline $2-5.6$ & 3.4965 & 4.12 & 3.11 & 5.46 & 5.46 & 5.46 & 5.46 \\
\hline $5.6-8$ & 6.7289 & 3.44 & 2.59 & 4.88 & 4.88 & 4.88 & 4.88 \\
\hline $8-11.2$ & 9.5106 & 3.13 & 2.36 & 4.60 & 4.60 & 4.60 & 4.60 \\
\hline $11.2-16$ & 13.4578 & 2.84 & 2.14 & 4.34 & 4.34 & 4.34 & 4.34 \\
\hline $16-22.4$ & 19.0211 & 2.58 & 1.95 & 4.09 & 4.09 & 4.09 & 4.09 \\
\hline $22.4-31.5$ & 26.6923 & 2.58 & 1.95 & 4.09 & 4.09 & 4.09 & 4.09 \\
\hline
\end{tabular}

\subsection{Calculating minimum bitumen content}

The percentage of the narrow fractions compounding the minerals of the designed asphalt mixture is presented in Table 5.

The results of calculating minimal bitumen content using the mathematical analogue (7) are displayed in Table 6. The first line contains the solution when no technological limitations were introduced. The second and third lines contain the results related to additional technological limitations, two of which, in practice, are used most commonly. First, the content of the crushed grains of the asphalt mixture dependent on the mass ratio of granite sifting and natural quartz sand is limited. Second, the mass ratio of imported fillers and reclaimed dust separated in the bag house of the asphalt mixing plant is also limited. Both of these requirements are specified in documents DAT.AD-96 (1997) and R 35-01 (2001).

Additional technological requirements (content of rubble subject to the mass ratio of granite screenings (GS) to natural sand (NS) and the ratio of imported filler (IF) to the reclaimed dust $(\mathrm{RD})$ in the baghouses of the asphalt mixing plant) are provided in specifications DAT.AD-96 (1997) and R 35-01 (2001).

The second line contains the results obtained under accepted technological limitations indicating that the asphalt mixture should include more than $3 \%$ of imported filler. The third line shows the results obtained under accepted technological limitations demonstrating that the asphalt mixture should include more than $3 \%$ of imported filler and less than $20 \%$ of natural sand. It is obvious that, under stronger technological requirements, minimal bitumen content increased. 
Table 5. The percentage of the narrow fractions compounding the mineral materials of the asphalt mixture calculated using percent passing values (Table 1)

\begin{tabular}{ccccccc}
\hline \multirow{2}{*}{$\begin{array}{c}\text { Sieve size, mm } \\
\text { (size fractions) }\end{array}$} & \multicolumn{7}{c}{ Content of the narrow fraction, $\%$} \\
\hline passing 0.063 & IF & NS & GS & CG4/8 & CG8/11 & CG11/16 \\
\hline $0.063-0.125$ & 9.6 & 4.2 & 11.3 & 2.6 & 2.1 & 1.8 \\
\hline $0.125-0.25$ & 4.5 & 11.7 & 10.8 & 0.5 & 0.2 & 0.3 \\
\hline $0.25-0.5$ & 1.6 & 17.8 & 7.7 & 0.6 & 0.4 & 0.4 \\
\hline $0.5-1$ & 0.3 & 13.3 & 10.5 & 0.7 & 0.5 & 0.4 \\
\hline $1-2$ & 0.2 & 11.3 & 7.5 & 4.1 & 0.7 & 0.7 \\
\hline $2-5.6$ & 0 & 23.2 & 38.6 & 7.9 & 2.8 & 1.6 \\
\hline $5.6-8$ & 0 & 8.7 & 8.2 & 73.4 & 5.3 & 3.8 \\
\hline $8.0-11.2$ & 0 & 3.9 & 0 & 9.2 & 82.1 & 5.5 \\
\hline $11.2-16$ & 0 & 0 & 0 & 0.7 & 4.8 & 74.3 \\
\hline $16-22.4$ & 0 & 0 & 0 & 0 & 0.9 & 10.1 \\
\hline $22.4-31.5$ & 0 & & 0 & 0 & 0 & 0.9 \\
\hline Total & 100 & 100 & 100 & 100 & 100 & 100 \\
\hline
\end{tabular}

Table 6. The results of simulating minerals and bitumen content in the asphalt mixture

\begin{tabular}{|c|c|c|c|c|c|c|c|}
\hline \multirow{2}{*}{$\begin{array}{l}\text { Technological } \\
\text { limitation }\end{array}$} & \multicolumn{6}{|c|}{ Content of the stockpile mineral material \% } & \multirow{2}{*}{$\begin{array}{l}\text { Bitumen } \\
\text { content, \% }\end{array}$} \\
\hline & IF & NS & GS & CG4/8 & CG8/11 & CG11/16 & \\
\hline No limitation & 2.0 & 62.0 & 0 & 0 & 0.8 & 35.2 & 5.00 \\
\hline $\mathrm{IF} \geq 3 \%$ & 3.0 & 57.5 & 0 & 0 & 4.7 & 34.8 & 5.07 \\
\hline IF $\geq 3 \%$ and $N S \leq 20 \%$ & 3.0 & 20.0 & 33.7 & 2.5 & 6.2 & 34.6 & 5.85 \\
\hline
\end{tabular}

\subsection{Determining minimum cost of mineral part of asphalt mixture}

The problem of determining the minimal cost of mineral materials contained in the asphalt mixture was solved using the mathematical analogue (7) and the object function (8). The following average costs of 1 tonne of mineral materials were fixed: non-activated dolomite imported filler $-30.00 €$, natural quartz sand $-1.50 €$, granite sifting $-14.50 €$ and all fractions of crushed granite $-21.00 €$. Under agreement that the cost of 1 tonne of bitumen was equal to $220.00 €$, the cost of the mineral part of designed asphalt mixtures was calculated. The results are presented in Table 7.

The second line contains the results obtained under accepted technological limitations and suggesting that the asphalt mixture should include more than $3 \%$ of imported filler. The third line contains the results obtained under accepted technological limitations indicating that the asphalt mixture should include more than $3 \%$ of imported filler and less than $20 \%$ of natural sand.

It is clear that, under stronger technological requirements, the cost of both minerals and asphalt mixtures increased. 
Table 7. The minimal cost of the mineral part, bitumen and asphalt mixture

\begin{tabular}{|c|c|c|c|c|c|c|c|c|c|c|}
\hline \multirow[b]{2}{*}{$\begin{array}{c}\text { Techno- } \\
\text { logical } \\
\text { limitation }\end{array}$} & \multicolumn{7}{|c|}{ Content of mineral materials and bitumen, $\%$} & \multicolumn{3}{|c|}{ Price (cost), EUR/t } \\
\hline & IF & NS & GS & CG4/8 & CG8/11 & CG11/16 & Bitumen & $\begin{array}{c}\text { All } \\
\text { mineral } \\
\text { materials }\end{array}$ & Bitumen & $\begin{array}{l}\text { Asphalt } \\
\text { mixture }\end{array}$ \\
\hline $\begin{array}{c}\text { No } \\
\text { limitation }\end{array}$ & 2.1 & 62.0 & 0 & 0 & 19.6 & 16.3 & 5,07 & 9.10 & 11.15 & 20.25 \\
\hline $\mathrm{IF} \geq 3 \%$ & 3.0 & 60.2 & 0 & 0 & 1.7 & 35.1 & 5,08 & 9.53 & 11.18 & 20.71 \\
\hline $\begin{array}{c}\mathrm{IF} \geq 3 \% \\
\quad \text { and } \\
\mathrm{NS} \leq 20 \%\end{array}$ & 3.0 & 20.0 & 45.0 & 0 & 0 & 32.0 & 6,56 & 14.44 & 14.43 & 28.87 \\
\hline
\end{tabular}

\subsection{Designing the densest asphalt mixture}

For illustrating an algorithm for simulating the densest gradation of mineral materials contained in the asphalt mixture, a problem of the minimal cost was selected. It was assumed that following the usual step of calculation, the interval between the specific points $p_{L i}$ and $p_{U i}$ of gradation limit curves was narrowed by $20 \%$. Calculation results are presented in Table 8 . The first four lines contain the solutions obtained when no technological limitations were introduced. Lines five and six propose the solutions obtained under the accepted technological limitations imposing that the asphalt mixture should include more than $3 \%$ of imported filler (IF) and less than $20 \%$ of natural sand (NS).

Table 8. The results of calculating the densest gradation of the mineral part

\begin{tabular}{|c|c|c|c|c|c|c|c|c|c|}
\hline \multirow{2}{*}{$\begin{array}{l}\text { Asphalt } \\
\text { mixture }\end{array}$} & \multirow{2}{*}{$\begin{array}{l}\text { Step } \\
\text { No }\end{array}$} & \multicolumn{6}{|c|}{ Content of mineral materials, $\%$} & \multirow{2}{*}{$\begin{array}{l}\text { Correlation } \\
\text { coefficient } r\end{array}$} & \multirow{2}{*}{$\begin{array}{l}\text { Cost of the } \\
\text { mineral part } \\
\text { (EUR) }\end{array}$} \\
\hline & & MM & GKS & GA & $\begin{array}{l}\text { GS } \\
4 / 8\end{array}$ & $\begin{array}{c}\text { GS } \\
8 / 11\end{array}$ & GS $11 / 16$ & & \\
\hline \multirow{4}{*}{ No limitation } & 1 & 2.1 & 62.0 & 0 & 0 & 19.6 & 16.3 & 0.995 & 9.10 \\
\hline & 2 & 2.6 & 58.9 & 0 & 0.1 & 20.5 & 18.0 & 0.995 & 9.75 \\
\hline & 3 & 2.8 & 53.2 & 3.5 & 14.8 & 5.2 & 20.6 & 0.997 & 10.65 \\
\hline & 4 & 2.1 & 38.2 & 20.3 & 11.0 & 6.1 & 22.4 & 0.999 & 12.41 \\
\hline \multirow{2}{*}{$\begin{array}{c}\mathrm{IF} \geq 3 \% \text { and } \\
\mathrm{NS} \leq 20 \%\end{array}$} & 1 & 3.0 & 20.0 & 45.0 & 0 & 0 & 32.1 & 0.998 & 14.44 \\
\hline & 2 & 3.0 & 20.0 & 40.5 & 0 & 3.3 & 33.2 & 0.998 & 14.73 \\
\hline
\end{tabular}

Since the theory of correlation is rich, we focused attention to the two most relevant types of the correlation coefficient, including Pearson and Spearman coefficients. Pearson reflects linear relationship between two variables (Yang 2008; Ban et al. 2016) and can be calculated by $y$ :

$$
r=\frac{\sum_{i=1}^{n}\left(x_{i}-\bar{X}\right)\left(y_{i}-\bar{Y}\right)}{\sqrt{\sum_{i=1}^{n}\left(x_{i}-\bar{X}\right)^{2}} \sqrt{\sum_{i=1}^{n}\left(y_{i}-\bar{Y}\right)^{2}}}
$$


where $x_{i}$ an $y_{i}$ are percent passing through the sieve respectively according technical requirements and calculated values; $\bar{X}=$ mean of variable $x, \bar{Y}=$ mean of variable $y ; n=$ number of sieves. The range of $r$ value $=-1$ to 1 .

In general, $|r|<0.4$ suggests poor linear correlation, $0.4 \leq|r|<0.7$ indicates significant correlation, and $0.7 \leq|r|<1.0$ stands for highly linear correlation (Gao et al. 2016).

The lowest value of correlation coefficient $r_{\text {min }}$ is calculated according to equation (14) and is as follows (Podvezko, Sivilevičius 2013):

$$
r_{\min }=\frac{t_{\alpha, v}}{\sqrt{n-2+t_{\alpha, v}^{2}}} .
$$

Given significant level $\alpha=0.05$ and $t$ - statistic $t_{\alpha, v}=1.833$ (when percent passing through 11 sieves is compared and the degree of freedom equals $v=n-2=9$ ), the lowest value of the correlation coefficient allowing us to consider that the variables correlate is equal to 0.521 .

In both cases, the correlation of the averages of percent passing of the calculated specification limits and percent passing of the obtained asphalt mixtures are presented in Figure 3.

The given examples show wide possibilities of the mathematical analogue (7) that could provide the asphalt mixture with the minimal content of the required bitumen, the minimal cost of the mineral part or the asphalt mixture containing the densest gradation of mineral materials. Moreover, for determining optimal asphalt mixtures considering one or another optimal criterion, solutions can be additionally simulated by introducing technological etc. types of limitations.

\section{Conclusions}

1. The mathematical model (7) and algorithms produced in the article may be used for a) designing asphalt mixtures with the minimal content of bitumen, the minimal cost of the mineral part and the densest gradation; b) evaluating technological requirements for producing the asphalt mixture; $c$ ) determining whether the available mineral materials can be employed for designing the asphalt mixture of the considered gradation; d) analysing solutions that do not satisfy the accepted limitations.

2. For producing asphalt mixtures in Lithuania, a small number of different mineral materials are used. Therefore, it is worth specifying the bitumen capacities of the narrow fractions of mineral materials using road and polymer-modified bitumen. Then, using the mathematical analogue (7) and algorithms applied in the paper, various criteria satisfying asphalt mixtures should be designed thus reducing both the cost of the asphalt mixture and the scope of high-priced laboratory works.

3. The analysis of the calculation experiment using real materials and setting out TRA ASPHALTAS 08 requirements shows that minimal bitumen content without and with certain technological limitations ranged from $5.00 \%$ to $5.85 \%$ (Table 6). The standard minimal content is equal to $5.2 \%$. The obtained results are close and indicate that the mathematical analogue (7) and algorithms allow obtaining real results. The application of this analogue should improve the design quality of asphalt mixtures and the prediction of their physical-mechanical properties. 
a)

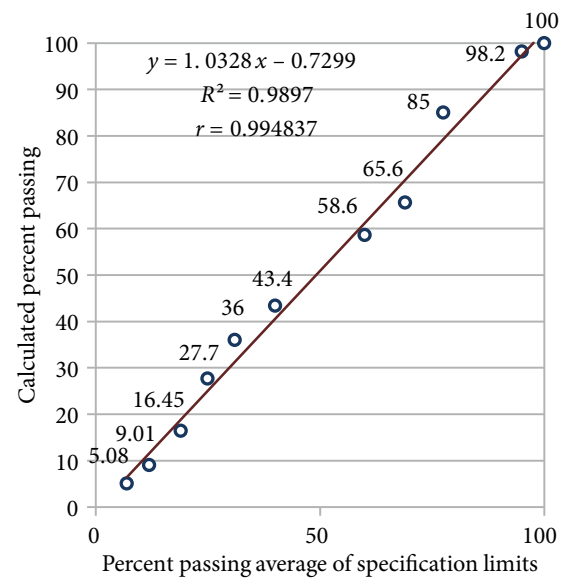

c)

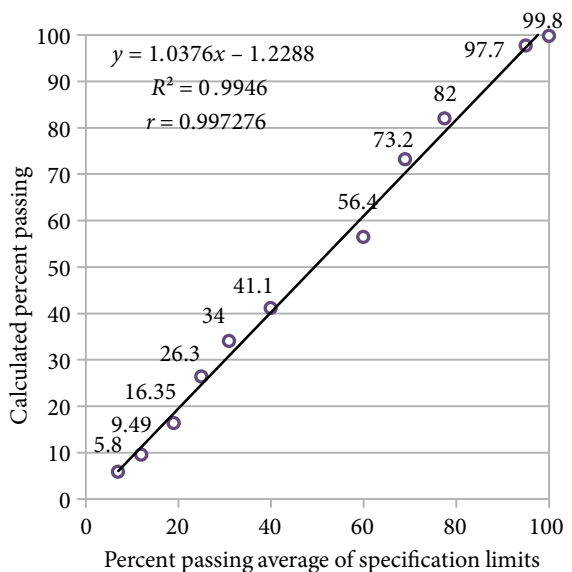

99.9

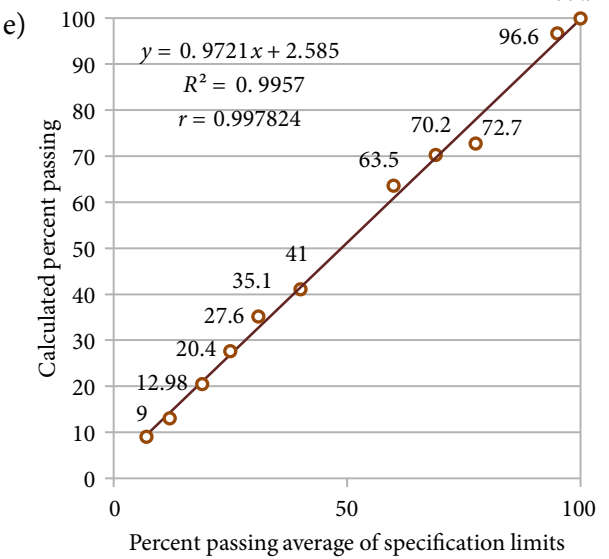

b)

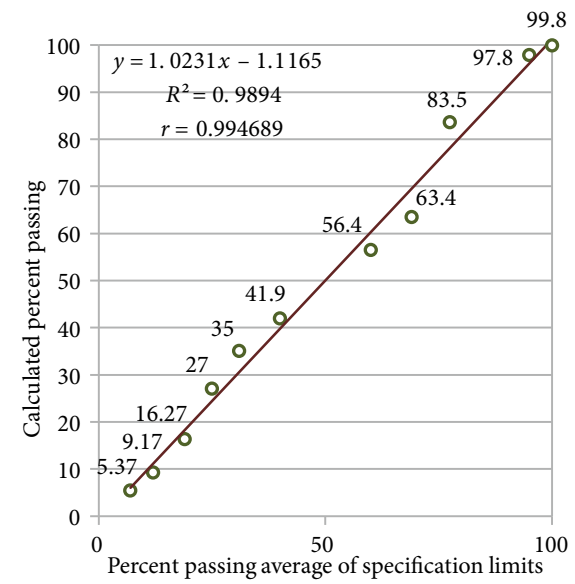

d)
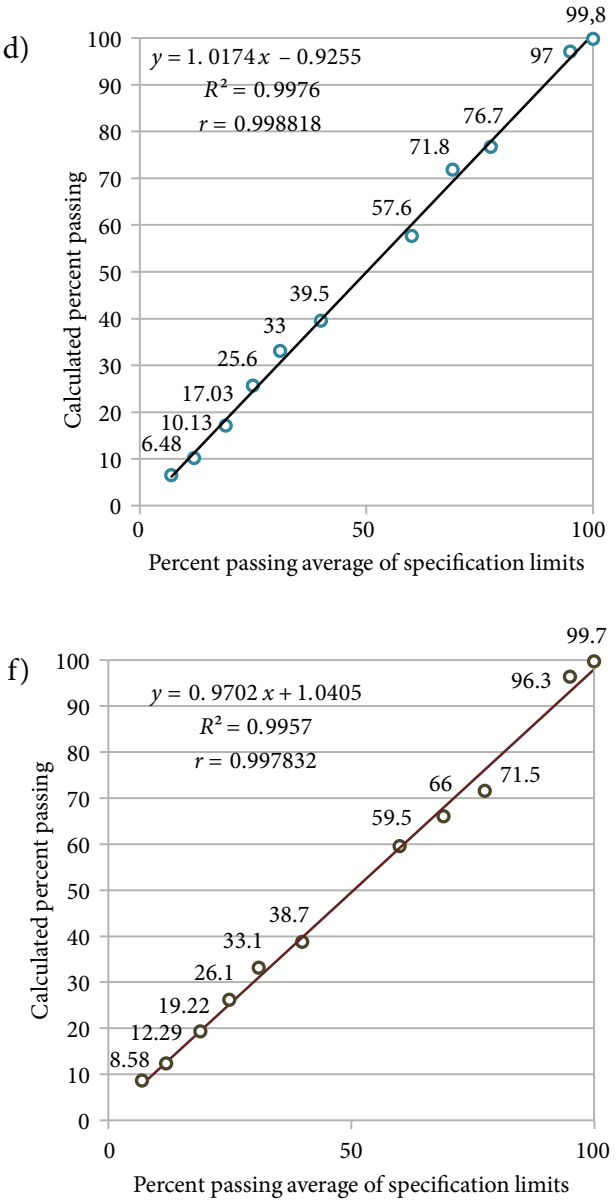

Fig. 3. The correlation of the averages of percent passing of specification limits and percent passing of the designed asphalt mixture under no technological limitations (a, b, c, d) when the imported filler had to make more than $3 \%$ and quartz sand had to make less than $20 \%(\mathrm{e}, \mathrm{f})$ 


\section{References}

Ahmad, J.; Abdul Rahman, M. Y.; Hainin, M. R.; Hossain, M. 2012. Comparative evaluation of hot-mix asphalt design methods, International Journal of Pavement Engineering 13(2): 89-97. https://doi.org/10.1080/10298436.2011.565576

Alam, S. Y.; Hammoum, F. 2015. Viscoelastic properties of asphalt concrete using micromechanical self-consistent model, Archives of Civil and Mechanical Engineering 15(1): 272-285. https://doi.org/10.1016/j.acme.2014.02.005

Androjić, I.; Dimter, S. 2015. Influence of compaction temperature on the properties of Marshall specimens, The Baltic Journal of Road and Bridge Engineering 10(4): 309-315. https://doi.org/10.3846/bjrbe.2015.39

Apeagyei, A. 2011. Rutting as a function of dynamic modulus and gradation, Journal of Materials in Civil Engineering 23(9): 1302-1310. https://doi.org/10.1061/(ASCE)MT.1943-5533.0000309

Awuah-Offei, K.; Askari-Nasab, H. 2009. Asphalt mix design optimization for efficient plant management, Transformation Research Record 2098: 105-112. https://doi.org/10.3141/2098-11

Awuah-Offei, K.; Askari-Nasab, H. 2011. Aggregate cost minimization in hot-mix asphalt design, Journal of Materials in Civil Engineering 23(5): 554-561. https://doi.org/10.1061/(ASCE)MT.1943-5533.0000211

Ban, O.-I.; Tara, I. G.; Bogdan, V.; Tuşe, D.; Bologa, G. 2016. Evaluation of hotel quality attribute importance trough fuzzy correlation coefficient, Technological and Economic Development of Economy 22(4): 471-492. https://doi.org/10.3846/20294913.2016.1144657

Behzadfar, E.; Hatzikiriakos, S. G. 2013. Viskoelastic properties and constitutive modelling of bitumen, Fuel 108: 391-399. https://doi.org/10.1016/j.fuel.2012.12.035

Bražiūnas, J.; Sivilevičius, H. 2010. The bitumen batching system's modernization and its effective analysis at the asphalt mixing plant, Transport 25(3): 325-335. https://doi.org/10.3846/transport.2010.40

Bražiūnas, J.; Sivilevičius, H.; Virbickas, R. 2013. Dependences of SMA mixture and its bituminous binder properties on bitumen batching system, mixing time and temperature on asphalt mixing plant, Journal of Civil Engineering and Management 19(6): 862-872. https://doi.org/10.3846/13923730.2013.843587

Castillo, D.; Caro, S. 2014. Effects of air voids variability on the thermo-mechanical response of asphalt mixtures, International Journal of Pavement Engineering 15(1-2): 110-121. https://doi.org/10.1080/10298436.2013.837464

Chang, C.-M.; Baladi, G. Y.; Wolff, T. F. 2002. Detecting segregation in bituminous pavements, Transportation Research Record 1813: 77-86. https://doi.org/10.3141/1813-10

Chen, J.; Huang, B.; Shu, X. 2013. Air-void distribution analysis of asphalt mixture using discrete element method, Journal of Materials in Civil Engineering 25(10): 1375-1385. https://doi.org/10.1061/(ASCE)MT.1943-5533.0000661

Chen, S.-H.; Lin, J.-D.; Huang, D.; Hung, C.-T. 2015. Effect of film thickness and voids in mineral aggregate in basic oxygen furnace slag dense-graded asphalt concrete, Journal of Testing and Evaluation 43(2): 229-236. https://doi.org/10.1520/JTE20140079

Chun, S.; Rogue, R.; Zou, J. 2012. Effect of gradation characteristics on performance of Superpave mixture in the field, Transportation Research Record 2294: 43-52. https://doi.org/10.3141/2294-05

Collop, A. C.; McDowell, G. R.; Lee, Y. W. 2006. Modelling dilation in an idealised asphalt mixture using discrete element modelling, Granular Matter 8(3-4): 175-184.

https://doi.org/10.1007/s10035-006-0013-3

Crouch, L. K.; Copeland, A. R.; Wolker, C. D.; Maxwell, R. A.; Duncan, G. M.; Goudwin, W. A.; Badoe, D. A.; Leimer, H. W. 2002. Determining air void content of compacted hot-mix asphalt mixtures, Transportation Research Record 1813: 39-46. https://doi.org/10.3141/1813-05 
DAT.AD-96. 1997. Automobiliu keliu tiesimo ir darbu priemimo taisykles: asfaltbetonio dangos. Lietuvos Respublikos Susisiekimo ministerija. Valstybès įmone "Problematika", Vilnius. 76 p. (in Lithuanian).

Doyle, J. D.; Howard, I. L.; Robinson, W. J. 2012. Prediction of absorbed, inert, and effective bituminous quantities in reclaimed asphalt pavement, Journal of Materials in Civil Engineering 24(1): 102-112. https://doi.org/10.1061/(ASCE)MT.1943-5533.0000356

Du, J.-C.; Kuo, M.-F. 2011. Grey relation-regression analysis for hot mix asphalt design, Construction and Building Materials 25(5): 2627-2634. https://doi.org/10.1016/j.conbuildmat.2010.12.011

Dubois, V.; De La Roche, C.; Burban, O. 2010. Influence of the compaction process on the air void homogeneity of asphalt mixtures samples, Construction and Building Materials 24(6): 885-897. https://doi.org/10.1016/j.conbuildmat.2009.12.004

Gajewski, M.; Sybilski, D.; Bańkowski, W. 2015. The influence of binder rheological properties in asphalt mixture permanent deformation, The Baltic Journal of Road and Bridge Engineering 10(1): 54-60. https://doi.org/10.3846/bjrbe.2015.07

Gao, C.; Deng, S.; Jiang, X.; Guo, Y. 2016. Analysis for the relationship between concentrations of air pollutants and meteorological parameters in Xian, China, Journal of Testing and Evaluation 44(3):1064-1076. https://doi.org/10.1520/JTE20140297

GOST 9128-76. Smesi asfal'tobetonnye dorozhnye, aerodromnye i asfal'tobeton. Tekhnicheskie usloviya. Moskva: Izdatel'stao standartov (in Russian).

Guarin, A.; Rique, R.; Kim, S.; Sirin, O. 2013. Description factor of asphalt mixtures, International Journal of Pavement Engineering 14(5-6): 472-485. https://doi.org/10.1080/10298436.2012.727992

Hasemi, E.; Jelagin, D.; Krongos, N.; Birgisson, M. 2012. An empirical framework for determining asphalt mastic viscosity as a function of mineral filler concentration, Construction and Building Materials 35(10): 23-29. https://doi.org/10.1016/j.conbuildmat.2012.02.093

Herrington, P. R. 2012. Diffusion and reaction of oxygen in bitumen films, Fuel 94: 86-92. https://doi.org/10.1016/j.fuel.2011.12.021

Highway Research Board. 1967. Evaluation of Construction Control Procedures. Interim Report. National cooperative highway research program. Report $34.117 \mathrm{p}$.

Hmoud, H. R. 2011. Evaluation of VMA and film thickness requirements in hot-mix asphalt, Modern Applied Science 5(4): 166-176. https://doi.org/10.5539/mas.v5n4p166

Hýzl, P.; Dašek, O.; Varaus, M.; Stehlik, D.; Coufalic, P.; Daškova, J.; Krčmová, I.; Nekulova. P. 2016. The effect of compaction degree and binder content of performance properties of asphalt mixtures, The Baltic Journal of Road and Bridge Engineering 11(3): 222-232. https://doi.org/10.3846/bjrbe.2016.26

Jin, X.; Cui, Y.; Glover, C. J. 2013. Modelling asphalt oxidation in pavement field validation, Petroleum Science and Technology 31(13): 1398-1405. https://doi.org/10.1080/10916466.2012.665115

IT ASFALTAS 08. 2008. Automobiliu keliu dangos konstrukcijos asfalto sluoksniu irrengimo taisykles. Lietuvos automobilių kelių direkcija, Vilnius. 62 p. (in Lithuanian).

Jitsangiam, P.; Chindaprasirt, P.; Nikraz, H. 2013. An evaluation of the suitability of SUPERPAVE and Marschall asphalt mix designs as they relate to Tailand's climatic conditions, Construction and Building Materials 40: 961-970. https://doi.org/10.1016/j.conbuildmat.2012.11.011

Kandhal, O. S.; Chakraborty, S. 1996. Evaluation of voids in the mineral aggregate for HMA paving mixtures. NCAT Report No 96-4. 35 p.

Kassem, E.; Masad, E.; Lytton, R.; Chowdhury, A. 2011. Influence of air voids on mechanical properties of asphalt mixtures, Road Materials and Pavement Design 12(3): 493-524. https://doi.org/10.1080/14680629.2011.9695258

Kok, B. V.; Kuloglu, N. 2011. Effects of two-phase mixing method on mechanical properties of hot mix asphalt, Road Materials and Pavement Design 12(4): 721-738.

https://doi.org/10.1080/14680629.2011.9713892 
Korolev, I. V. 1986. Puti ekonomii bituma v dorozhnom stroitel'stve. Moskva: Transport. 149 s. (in Russian).

Liu, Y.; You, Z.; Dai, Q.; Mills-Beale, J. 2011. Review of advances in understanding impacts of mix composition characteristics on asphalt concrete (AC) mechanics, International Journal of Pavement Engineering 12(4): 385-405. https://doi.org/10.1080/10298436.2011.575142

Luo, R.; Lytton, R. L. 2013. Selective absorption of asphalt binder by limestone aggregates in asphalt mixtures, Journal of Materials in Civil Engineering 25(2): 219-226. https://doi.org/10.1061/(ASCE)MT.1943-5533.0000578

Mieczkowski, P. 2015. The heat exchange the edge area - the problem of hot mix asphalt compaction, The Baltic Journal of Road and Bridge Engineering 10(3): 207-215. https://doi.org/10.3846/bjrbe.2015.26

Asphalt Institute. 1993. Mix design methods for asphalt concrete and other hot-mix types (Manual Series No2 (MS-2)). $6^{\text {th }}$ ed. Asphalt Institute, Lexington: $141 \mathrm{p}$.

Mogawer, W. S.; Austerman, A. J.; Bonaquist, R. 2012. Determining the influence of plant type and production parameters on performance of plant-produced reclaimed asphalt pavement mixtures, Transportation Research Record 2268: 71-81. https://doi.org/10.3141/2268-09

Mohammad, L. N.; Wu, Z.; Zhang, C.; Khattak, M. J.; Abadie, C. 2004. Variability of air voids and mechanic properties of plant-produced asphalt mixtures, Transportation Research Record 1891: 85-102. https://doi.org/10.3141/1891-12

Oliver, J. 2011. The effect of binder film thickness in asphalt cracking and ravelling, Road \& Transport Research: a Journal of Australian and New Zeland Research and Practice 20(3): 3-13.

Özgan, E.; Serin, S.; Kap, T. 2013. Multi-faceted investigation into the effects of hot-mix asphalt parameters on Marschall Stability, Construction and Building Materials 40: 419-425.

https://doi.org/10.1016/j.conbuildmat.2012.11.002

Paliukaite, M.; Vaitkus, A. 2015. Influence of bitumen chemical composition and ageing on pavement performance, The Baltic Journal Road and Bridge Engineering 10(1): 97-104. https://doi.org/10.3846/bjrbe.2015.12

Podvezko, V.; Sivilevičius, H. 2013. The use of AHP and rank correlation methods for determining the significance of the interaction between the elements of a transport system having a strong influence on traffic safety, Transport 28(4): 389-403. https://doi.org/10.3846/16484142.2013.866980

Praticó, F. G.; Moro, A. 2012. Measurement of air voids content in hot mix asphalts: method and core diameter dependence, Construction and Building Materials 26(1): 344-349.

https://doi.org/10.1016/j.conbuildmat.2011.06.032

R 35-01. 2001. Statybos rekomendacijos. Automobiliu keliu asfaltbetonio ir žvyro dangos. Lietuvos automobilių kelių direkcija prie Susisiekimo ministerijos. 117 p. (in Lithuanian).

Radovskiy, B. 2003. Analytical formulas for film thickness in compacted asphalt mixture, Transportation Research Record 1829: 25-32. https://doi.org/10.3141/1829-04

Read, J.; Whiteoak, D.; Whiteok, D. 2003. The Shell Bitumen Handbook. $5^{\text {th }}$ ed. London: Thomas Telford Ltd. $464 \mathrm{p}$.

Remišová, E. 2015. Effect of film thickness on resistance to permanent deformation in asphalt mixtures, The Baltic Journal of Road and Bridge Engineering 10(4): 333-339.

https://doi.org/10.3846/bjrbe.2015.42

Rimša, V.; Kačianauskas, R.; Sivilevičius, H. 2014. Numerical analysis of asphalt mixture and composition with physical Marshall test, Journal of Civil Engineering and Management 20(4): 570-580. https://doi.org/10.3846/13923730.2014.920413 
Roberts, F. L.; Mohammad, L. N.; Wang L. B. 2002. History of hot mix asphalt mixture design in the United States, Journal of Materials in Civil Engineering 14(4): 279-293. https://doi.org/10.1061/(ASCE)0899-1561(2002)14:4(279)

Rukovodstvo po stroitel'stvu dorozhnykh asfal'tobetonnykh pokrytiy. 1978. Moskva: Transport. 92 p. (in Russian).

Sánchez-Leal, F. J.; Anguas, P. G.; Larreal, M.; López Valdes, D. B. 2011. Polyvoids: analytical tool for Superpave HMA design, Journal of Materials in Civil Engineering 23(8): 1129-1137. https://doi.org/10.1061/(ASCE)MT.1943-5533.0000275

Sengoz, B.; Agar, E. 2007. Effect of asphalt film thickness on the moisture sensitivity characteristics of hot-mix asphalt, Building and Environmental 42(10): 3621-3628. https://doi.org/10.1016/j.buildenv.2006.10.006

Sengoz, B.; Topal, A. 2007. Minimum voids in mineral aggregate in hot-mix asphalt based film thickness, Building and Environment 42(10): 3629-3635. https://doi.org/10.1016/j.buildenv.2006.10.005

Seo, Y.; El-Haggan, O.; King, M.; Lee, J.; Kim, Y. R. 2007. Air voids models for the dynamic modulus, fatigue cracking, and rutting of asphalt concrete, Journal of Materials in Civil Engineering 19(10): 874-883. https://doi.org/10.1061/(ASCE)0899-1561(2007)19:10(874)

Shen, S.; Yu, H. 2011. Analysis of aggregate gradation and packing for easy estimation of hot-mixasphalt voids in mineral aggregate, Journal of Materials in Civil Engineering 23(5): 664-672. https://doi.org/10.1061/(ASCE)MT.1943-5533.0000224

Sivilevičius, H.; Vansauskas, V. 2013. Research and evaluation of ruts in the asphalt pavement on Lithuanian highways, Journal of Civil Engineering and Management 19(5): 609-621. https://doi.org/10.3846/13923730.2013.817481

TRA ASFALTAS 08. 2008. Automobilių kelių asfalto mišiniu techninių reikalavimu aprašas. Lietuvos automobilių kelių direkcija. Vilnius. 61 p. (in Lithuanian).

Transportation Research Board. 2011. NCHRP Report 673. A Manual for Design of Hot Mix Asphalt with Commentary. Transportation Research Board. Washington, D. C. 273 p.

Underwood, B. S.; Kim, Y. R. 2013. Microstructural investigation of asphalt concrete for performing multiscale experimental studies, International Journal of Pavement Engineering 14(5-6): 498-516. http://dx.doi.org/10.1080/10298436.2012.746689

Vaitkus, A.; Paliukaitè, M. 2013. Evaluation of time loading influence on asphalt pavement rutting, Procedia Engineering 57: 1205-1212. https://doi.org/10.1016/j.proeng.2013.04.152

Vasconcelos, K. L.; Bhasin, A.; Little, D. N. 2011. History dependence of water diffusion in asphalt binders, International Journal of Pavement Engineering 12(5): 497-506. https://doi.org/10.1080/10298436.2010.535536

Vavrik, W. R.; Pine, W. J.; Carpenter, S. H. 2002. Aggregate blending for asphalt mix design. Bailey method, Transportation Research Record 1789: 146-153. https://doi.org/10.3141/1789-16

Vislavičius, K. 2000. Bendrieji konglomeratų fizikinių-mechaninių savybių modeliavimo principai, Statyba 6(3): 175-178. (in Lithuanian). https://doi.org/10.1080/13921525.2000.10531584

Vislavičius, K. 2002. Determination of optimum quantity of bitumen in asphalt concrete mixtures, Journal of Civil Engineering and Management 8(1): 73-76. https://doi.org/10.1080/13923730.2002.10531252

Vislavičius, K.; Sivilevičius, H. 2013. Effect of reclaimed asphalt pavement gradation variation on the homogeneity of recycled hot-mix asphalt, Archives of Civil and Mechanical Engineering 13(3): 345353. https://doi.org/10.1016/j.acme.2013.03.003

Watson, D. E.; Masad, E.; Moore, K. A.; Williams, K.; Cooley, L. A. Ir. 2004. Verification of voids in coarse aggregate testing. Determining stone-on-stone contact of hot-mix asphalt mixtures, Transportation Research Record 1891: 182-190. 
Xie, H.; Watson, D. E. 2004. Determining air voids content of compacted stone matrix asphalt mixtures, Transportation Research Record 1891: 203-211. https://doi.org/10.3141/1891-24

Yang, I-T. 2008. Distribution - free Monte Carlo simulation: premise and refinement, Journal of Construction Engineering and Management 134(5): 352-360. https://doi.org/10.1061/(ASCE)0733-9364(2008)134:5(352)

Yi, J.; Shen, S.; Wang, D.; Huang, Y.; Feng, D. 2016. Characterization of the bonding fracture properties of the asphalt-aggregates system using a thin-film interface test, Journal of Testing and Evaluation 44(1): 450-460. https://doi.org/10.1520/JTE20140409

Yiqiu, T.; Xiaolin, L.; Jiantao, W. 2012. Internal influence factors of asphalt-aggregate filler interactions based on rheological characteristics, Journal of Materials in Civil Engineering 24(12): 1520-1528. https://doi.org/10.1061/(ASCE)MT.1943-5533.0000506

Zaciada, W. A.; Kaloush, K. E.; Underwood, B. S.; Mamlouk, M. E. 2014. Improved method of considering air void and asphalt content changes on long-term performance of asphalt concrete pavements, International Journal of Pavement Engineering 15(7-8): 718-730. http://dx.doi.org/10.1080/10298436.2013.857775

Zhang, D.; Huang, X.; Zhao, Y. 2012. Investigation of the shape, size, angularity and surface texture properties of coarse aggregates, Construction and Building Materials 34(9): 330-336. https://doi.org/10.1016/j.conbuildmat.2012.02.096

Zulkati, A.; Diew, W. Y.; Delai, D. S. 2012. Effects of fillers on properties of asphalt-concrete mixture, Journal of Transportation Engineering 138(7): 902-910. https://doi.org/10.1061/(ASCE)TE.1943-5436.0000395

Henrikas SIVILEVIČIUS. Dr Habil. Prof. at the Department of Transport Technological Equipment of Vilnius Gediminas Technical University, Lithuania. PhD in road construction (1984). Dr Sc. (2003) in civil engineering. The author and co-author of more than 180 research papers. Research interests: hot mix asphalt (HMA) production quality and development of quality control methods, statistical and multiple-criteria decision making (MCDM) methods used in the transport system, methods for assessing the state and service life of the flexible road pavement, asphalt pavement recycling.

Kęstutis VISLAVIČIUS. Dr Assoc. Prof. at the Department of Strength of Materials and Engineering Mechanics of Vilnius Gediminas Technical University, Lithuania. PhD in structural mechanics (1977). The author and co-author of more than 60 research papers. Research interests: optimization problems of elastic-plastic structures, concrete, hot mix asphalt (HMA), bolted joints and traffic, discrete element method, computer-aided teaching.

Justas BRAŽIŪNAS. Dr Assoc. Prof. at the Department of Transport Technological Equipment of Vilnius Gediminas Technical University (VGTU), Lithuania. Research interests: technologies for producing a hot-mix asphalt mixture, bitumen storage, heating, pumping, metering and batching systems of asphalt mixing plants, short-term ageing of bitumen. 